\title{
DL - Methionine and Vitamin C Effects on Growth and Nutrient Metabolism of Guinea Pigs Supplemented with Dietary Lead
}

\author{
J.K. Bernard* and V. Dildeep \\ Department of Animal Nutrition, CVAS Pookode, Kerala Veterinary and Animal sciences, \\ Kerala, India \\ *Corresponding author
}

\begin{tabular}{|l|}
\hline Ke y w or d s \\
$\begin{array}{l}\text { Lead toxicity } \\
\text { growth and } \\
\text { metabolism, DL } \\
\text { methionine, } \\
\text { Vitamin C }\end{array}$ \\
\hline Article Info \\
\hline $\begin{array}{l}\text { Accepted: } \\
\text { 20 May } 2019 \\
\text { Available Online: } \\
\text { 10 June } 2019\end{array}$ \\
\hline
\end{tabular}

\section{Keywords}

Lead toxicity growth and metabolism, DL methionine, Vitamin C

\section{Introduction}

Among heavy metals lead $(\mathrm{Pb})$ which is a ubiquitous metal commonly encountered as environmental contaminant. Natural and antropogenic activities contribute to the lead burden in the environment. The common sources of lead include combustion of coal and mineral oil, use paints, batteries, smelters, mining, alloy processing units, paint industries, etc. Lead adversely affects various systems in animal body which includes nervous system, cardiovascular system along with different vital organs including liver, kidney and reproductive organs. Nutritional intervention using vitamins, amino acids and trace minerals are being proposed in modern therapeutic management of heavy metal intoxication in human and veterinary medicine. The present study was undertaken to assess the ameliorative effects of vitamin $\mathrm{C}$ and DL-methionine against lead toxicity in guinea pigs and to compare the ameliorative effects of vitamin $\mathrm{C}$ and DL-methionine 
against lead toxicity. Twenty four healthy guinea pigs (Cavia porcellus) of about 60 days of age were procured from Small Animal Breeding Station, Mannuthy. Animals were maintained for 7 days on a standard diet comprised of concentrate mixture and green fodder (Australian Napier) before the start of the proper experiment for adaptation. Animals were then divided into four groups of six animals in each group on the basis of their body weight following randomized block design (RBD). Animals of different groups under experiment were kept in 4 separate trays, with wood shavings as the bedding material in small animal breeding station, Pookode, under strict management and hygienic practices. The bedding material was changed daily. Clean drinking water was provided ad libitum. Experimental feeding lasted for a period of 90 days.

\section{Materials and Methods}

The study was conducted in 32 weaned guinea pigs which were procured from Small Animal breeding station, Mannuthy, Kerala, India. They were divided into four groups of 8 animals each using Randomized Block Design (RBD) based on their body weight. Group G1 (control) received a basal diet as per (NRC, 2005) and group G2 received basal diet+ 20 ppm lead acetate; G3 - basal diet +20 ppm $\mathrm{Pb}+20$ ppm DL-methionine; G4 . basal diet +20 ppm $\mathrm{Pb}+500$ ppm Vitamin C. Lead was given as aqueous solution of lead acetate; DL-methionine as aqueous solution of DLmethionine; and vitamin $\mathrm{C}$ as aqueous solution of L-ascorbic acid by dissolving known amount of distilled water. All the animals were maintained under strict hygienic environment for an experimental period of 90 days. Daily dry matter intake and weekly body weight gain were measured. A metabolism trial of four days duration was carried out after 45 days of experimental feeding to assess the nutrient digestibility and balance of nitrogen $(\mathrm{N})$, calcium $(\mathrm{Ca})$, phosphorus $(\mathrm{P})$, lead $(\mathrm{Pb})$.

\section{Recording of body weights and feed intake}

Weekly body weights of all the animals were recorded using an electronic balance (AREVY) in the morning time before offering them any feed or water. Animals were daily offered weighed amount of basal diet and residue was weighed after 24 hours of offering. Samples of the respective basal diet offered as well as residue left after 24 hours were subjected to dry matter analysis in order to find out the daily feed (DM) intake of the animals.

\section{Metabolism trial}

A metabolism trial of 4 days duration was conducted after 45 days of experimental feeding, to assess the nutrient digestibility and balance of nitrogen $(\mathrm{N})$, calcium $(\mathrm{Ca})$, phosphorus $(\mathrm{P})$ and lead $(\mathrm{Pb})$. Four animals from each group were randomly selected and kept in individual cages. An adaptation period of 2 days was given before collection of faeces and urine. The animals were fed individually with weighed amount of feed. Residue left and total faeces voided by the individual animals were collected after $24 \mathrm{~h}$ and weighed and representative sample of the residue and faeces was brought to the laboratory for further analysis. A suitable aliquot of faeces was daily transferred to a Kjeldahl digestion flask containing $25 \mathrm{ml}$ of commercial sulphuric acid for $\mathrm{N}$ estimation. A suitable aliquot of feed, faeces, fodder and residues were kept in hot air oven to estimate the DM content. Samples of 4 days were pooled together and stored in plastic sachets for individual animal for their further analysis. Weighed amount of feed was offered and residue was collected daily in the morning. Samples of four days were pooled together after grinding, and stored in plastic 
sachets for individual animal for their further analysis. The total faeces voided by individual animal during $24 \mathrm{~h}$ period was separately collected and weighed at a fixed time $(10.00$ A.M.) daily. A suitable sample of faeces was taken for DM estimation in a petridish and kept in hot air oven overnight. Dried samples were pooled for 4 days in polythene bags. For the estimation of nitrogen, another suitable aliquot was collected daily into a glass bottle containing 20 per cent sulphuric acid and pooled for four days separately for each animal. Urine voided was also collected and half sample of the urine was daily transferred into a Kjeldahl flask containing $15 \mathrm{ml}$ conc. commercial sulphuric acid for nitrogen estimation. Another half part of urine was preserved daily by refrigeration for the analysis of minerals.

Feed, fodder, residue and faeces samples were analyzed for proximate principles and urine for nitrogen as per AOAC (2000). Feeds and faeces samples were analyzed for neutral detergent fibre (NDF), acid detergent fibre (ADF) and acid detergent lignin (ADL) as per the methods of Van Soest et al., (1991). Calcium in feed, faeces and urine samples was estimated from the mineral extract following procedure of Talapatra et al., (1940). The phosphorus content of feed, faeces and urine samples were estimated from the mineral extract as per AOAC (2000) using UV visible spectrophotometer (Systronics 2201). Lead was estimated by atomic absorbance spectrophotometer (AAS) using Perkin Elmer analyst 400.

\section{Results and Discussion}

Mean DM intake (g/d) by guinea pigs in different groups at weekly interval

The data pertaining to the daily dry matter intake (DMI) and overall dry matter intake is given in table 1 . The overall dry matter intake is $30.5,30.4,30.5$ and 30.4 in groups $\mathrm{G} 1, \mathrm{G} 2$, G3 and G4 respectively. The mean dry matter intake in first week was 24.2, 24.1, 24.1, 24.1 and final week dry matter was 33.3, 33.2, 33.2 and 33.1 in G1, G2, G3 and G4 respectively. The DMI was similar $(\mathrm{P}>0.05)$ in the four groups of guinea pigs. Thus the DMI was not affected by dietary lead supplementation.

\section{Weekly body weight (g) gain in different group of guinea pigs}

Weekly mean bodyweight gain in guinea pigs is represented in table 2 . The overall mean body weight in G1, G2, G3 and G4 was 488.2, 486.5, 484.7, 475.83 and no statistical difference was observed between groups. The initial body weight $(\mathrm{g})$ in different groups was 336.2, 346.3, 353.0, and 355.0 and the final body weight $(\mathrm{g})$ in four groups was 561.7, $571.0,579.5$ and 578 in G1, G2, G3 and G4 respectively. There was no statistical significant difference among the groups in growth performance due to lead supplementation nor there was any effect due to addition of dietary ameliorating agents.

\section{Digestibility (\%) in different group of guinea pigs}

The digestibility of different nutrients in different groups of guinea pigs is given in table 3 . The dry matter digestibility in groups G1, G2, G3 and G4 were 74.4, 74.3, 74.3, and 75.1 and there was no statistical $(\mathrm{p}>0.05)$ difference between the four groups. The organic matter digestibility in groups G1, G2, G3 and G4 were 77.9, 76.9, 77.7 and 77.0 and were statistically non-significant $(\mathrm{p}>0.05)$. The digestibility of crude protein were 82.1, 81.2, 80.9 and 81.63 in G1, G2, G3 and G4 groups and no statistical $(p>0.05)$ difference could be observed. The ether extract digestibility in the four groups were 73.9, $71.9,73.10$ and 72.64 respectively and were statistically $(p>0.05)$ non-significant. The 
neutral detergent digestibility was 64.8, 65.4, 64.2 and 67.57 in the four groups and there was no statistical ( $p>0.05$ ) difference whereas the acid detergent digestibility was 58.2, 57.6, 57.6 and 57.9 and were statistically $(\mathrm{p}>0.05)$ in significant. The hemicelluloses digestibility $(\mathrm{p}>0.05)$ was 67.7, 67.4, 67.7, 67.7 and 67.7 in groups G1, G2, G3 and G4 respectively and the cellulose digestibility $(\mathrm{p}>0.05$ ) was noted as 63.3, 63.1, 63.4 and 63.1 among the four groups and was found to be statistically ( $\mathrm{p}>0.05$ ) comparable.

Intake and balance (g/d) of nitrogen, calcium, phosphorus and lead in different groups of guinea pigs

The intake and balance of nitrogen, calcium, phosphorous and lead in different groups of guinea pigs are represented in table 4. The nitrogen intake in G1, G2, G3 and G4 groups were $1.10,1.11,1.11$ and 1.12 respectively whereas the faecal outgo were $0.28,0.29$, 0.30 and 0.30 , and outgo through urine were $0.14,0.14,0.15$ and 0.15 respectively and the total nitrogen outgo were $0.42,0.43,0.45$ and 0.45 respectively. There was no statistical significance in total nitrogen intake, faecal nitrogen outgo, urine nitrogen outgo and the total nitrogen outgo. The balance of nitrogen in different groups were statistically $(\mathrm{p}>$ $0.05)$ alike.

The calcium intake among the four groups were statistically $(\mathrm{p}>0.05)$ alike and were 0.81 , in all groups. The faecal outgo of calcium significantly $(\mathrm{p}<0.01)$ increased in lead supplemented groups and was 0.36, 0.52, 0.52 and 0.52 respectively. The urine out go of calcium was 0.04 in all groups. The total out go of calcium in G1, G2, G3 and G4 groups were $0.40,0.56,0.56$ and 0.56 respectively and was found to be significantly ( $\mathrm{p}<0.01)$ increased in lead treated groups. The balance of calcium was $0.41,0.25,0.25$ and 0.25 respectively and statistically significant $(\mathrm{p}<0.01)$ difference were observed in G2, G3 and G4 groups which were supplemented with lead

The phosphorous intake in G1, G2, G3 and G4 were $0.43,0.42,0.42$ and 0.41 and faecal outgo of phosphorous was $0.17,0.15,0.16$ and 0.15 respectively and no statistically significant difference were observed in phosphorous intake and faecal outgo between the different groups.

The urine outgo of phosphorous in four groups were 0.03 in all groups and total outgo of phosphorous was $0.20,0.18,0.19$ and 0.18 respectively and showed no significant ( $p>$ 0.01 ) difference. The balance of phosphorous in G1, G2, G3 and G4 groups was 0.23, 0.24, 0.23 and 0.23 . There was no statistical ( $>0.01)$ significance in phosphorous balance between the four groups.

The lead intake in G1, G2, G3 and G4 groups were $0.06,0.65,0.64$ and 0.65 respectively and showed significantly increased lead intake in all the lead treated groups. No significant difference in lead intake were observed between DL Methionine treated group (G3) and L ascorbic acid treated group (G4). The faecal outgo of lead in four groups was $0.00,0.33,0.31$ and 0.31 respectively and significant difference $(\mathrm{p}<0.01)$ was observed between control group and all treatment groups. The urine outgo of lead in groups G1, G2, G3 and G4 were 0.01, 0.22, 0.24, and 0.29 respectively.

Outgo of lead through urine was significantly increased $(\mathrm{p}<0.01)$ in vitamin $\mathrm{c}$ treated group (G4) when compared to group (G3) where DL- Methionine was used as ameliorating agent. The total outgo of lead in four groups was $0.01,0.55,0.55$ and 0.60 respectively. Significant difference $(\mathrm{p}<0.01)$ existed between G3 and G4 with respect to total 
outgo of lead. The balance of lead in G1, G2, G3 and G4 groups was 0.05, 0.10, 0.08, 0.05 and significant differences were observed between groups.

\section{Dry matter intake in guinea pigs}

The mean dry matter intake showed no significant difference $(p>0.05)$ between the four groups, indicating that lead in feed at a concentration of $20 \mathrm{ppm}$ does not affect the feed intake. Similar results were obtained by Ibitoye et al., (2011) and Erdogan et al., (2005) in broilers fed with 200 mg dietary lead per $\mathrm{kg}$ of feed.

Shehata et al., (2011) noticed an improvement in daily feed intake and daily body weight gain in rabbits fed with lead and methionine when compared with group fed with lead without any ameliorative agent. Results of the present study indicated that addition of lower levels of dietary lead does not directly affect the dry matter intake of guinea pigs.

\section{Body weight gain in guinea pigs}

Weekly body weight gain and overall mean bodyweight did not show any significant $(\mathrm{p}>$ 0.05) difference. Damron et al., (1969) reported no change in body weight in broilers even at $2000 \mathrm{mg} / \mathrm{kg}$ body weight in seventy two weanling male Sprague - Dawley rats supplemented with either 0,50 or $100 \mathrm{mg}$ lead/ litre in their drinking water. The results are in accordance with Edward and Beatson (1985) who reported no significant changes in body weight in guinea pigs due to lead poisoning.

Contrary to our results, Randa et al., (2012) reported that guinea pigs receiving lead acetate at $5.5 \mathrm{mg}$ lead/ $\mathrm{kg}$ body weight showed decrease in bodyweight in third and fourth weeks post exposure. Logner et al., (1984) observed that feed intake and body weight gain were slightly decreased in lead supplemented calves and was more noticeable in higher dosed groups.

\begin{tabular}{|l|l|l|l|l|l|l|}
\hline \multicolumn{5}{|c|}{ Table.1 Mean DM intake (g/d) by guinea pigs in different groups at weekly interval } \\
\hline Week & Group & \multicolumn{3}{l|}{ SEM } & P value \\
\cline { 2 - 5 } & G1 & G2 & G3 & G4 & & \\
\hline 1 & 24.2 & 24.1 & 24.1 & 24.1 & 0.246 & 0.998 \\
\hline 2 & 26.6 & 26.5 & 26.6 & 26.5 & 0.080 & 0.887 \\
\hline 3 & 27.2 & 27.2 & 27.0 & 27.1 & 0.106 & 0.888 \\
\hline 4 & 29.7 & 29.7 & 29.7 & 29.4 & 0.166 & 0.859 \\
\hline 5 & 31.4 & 31.4 & 31.4 & 31.5 & 0.147 & 0.996 \\
\hline 6 & 33.6 & 33.3 & 33.6 & 33.5 & 0.203 & 0.945 \\
\hline 7 & 32.9 & 32.7 & 32.8 & 32.8 & 0.202 & 0.985 \\
\hline 8 & 32.5 & 32.2 & 32.5 & 32.4 & 0.203 & 0.953 \\
\hline 9 & 32.1 & 32.0 & 32.2 & 32.2 & 0.185 & 0.990 \\
\hline 10 & 31.6 & 31.4 & 31.5 & 31.6 & 0.201 & 0.977 \\
\hline 11 & 30.1 & 30.0 & 30.2 & 30.1 & 0.108 & 0.952 \\
\hline 12 & 32.0 & 31.8 & 32.0 & 31.9 & 0.172 & 0.980 \\
\hline 13 & 33.3 & 33.2 & 33.2 & 33.1 & 0.087 & 0.922 \\
\hline Mean DM intake & 30.5 & 30.4 & 30.5 & 30.4 & & \\
\hline
\end{tabular}




\begin{tabular}{|c|c|c|c|c|c|c|}
\hline \multirow[t]{3}{*}{ Week } & \multicolumn{4}{|c|}{ Group } & \multirow[t]{2}{*}{ SEM } & \multirow[t]{2}{*}{ P value } \\
\hline & G1 & G2 & G3 & G4 & & \\
\hline & \multicolumn{6}{|c|}{ Body weight } \\
\hline 1 & 336.2 & 346.3 & 353.0 & 355.0 & 14.23 & 0.971 \\
\hline 2 & 353.2 & 355.3 & 375.5 & 352.2 & 14.05 & 0.937 \\
\hline 3 & 387.5 & 380.2 & 400.2 & 379.2 & 14.66 & 0.961 \\
\hline 4 & 412.5 & 417.5 & 407.5 & 381.3 & 13.31 & 0.801 \\
\hline 5 & 475.7 & 460.7 & 467.7 & 438.0 & 13.40 & 0.801 \\
\hline 6 & 483.5 & 499.2 & 490.7 & 481.5 & 12.53 & 0.972 \\
\hline 7 & 538.8 & 527.5 & 502.3 & 499.3 & 14.41 & 0.746 \\
\hline 8 & 547.7 & 543.2 & 528.5 & 515.7 & 14.83 & 0.884 \\
\hline 9 & 552.3 & 538.3 & 517.7 & 537.2 & 16.53 & 0.729 \\
\hline 10 & 568.1 & 566.7 & 544.7 & 547.7 & 17.33 & 0.708 \\
\hline 11 & 575.2 & 554.5 & 563.2 & 555.3 & 17.23 & 0.307 \\
\hline 12 & 554.0 & 564.3 & 570.3 & 565.5 & 16.47 & 0.244 \\
\hline 13 & 561.7 & 571.0 & 579.5 & 578.0 & 16.74 & 0.319 \\
\hline Overall mean body weight & 488.2 & 486.5 & 484.7 & 475.8 & & \\
\hline
\end{tabular}

\begin{tabular}{|c|c|c|c|c|c|c|}
\hline \multicolumn{7}{|c|}{ Table.3 Digestibility (\%) in different group of guinea pigs } \\
\hline \multirow[t]{2}{*}{ Attribute (\%) } & \multicolumn{4}{|c|}{ Group } & \multirow[t]{2}{*}{ SEM } & \multirow[t]{2}{*}{ P valuc } \\
\hline & G1 & G2 & G3 & G4 & & \\
\hline DM & 74.4 & 74.3 & 74.3 & 75.1 & 0.22 & 0.973 \\
\hline $\mathrm{OM}$ & 77.9 & 76.9 & 77.7 & 77.0 & 0.63 & 0.929 \\
\hline $\mathrm{CP}$ & 82.1 & 81.2 & 80.9 & 81.6 & 0.30 & 0.595 \\
\hline $\mathrm{EE}$ & 73.9 & 71.9 & 73.1 & 72.6 & 0.38 & 0.343 \\
\hline NDF & 64.8 & 65.4 & 64.2 & 67.6 & 0.69 & 0.380 \\
\hline ADF & 58.2 & 57.6 & 57.6 & 57.9 & 0.51 & 0.936 \\
\hline Hemicelluloses & 67.7 & 67.4 & 67.7 & 67.7 & 0.16 & 0.923 \\
\hline Cellulose & 63.3 & 63.1 & 63.4 & 63.1 & 0.13 & 0.770 \\
\hline
\end{tabular}


Table.4 Intake and balance (g/d) of nitrogen, calcium, phosphorus and lead in different groups of guinea pigs

\begin{tabular}{|c|c|c|c|c|c|c|}
\hline \multirow[t]{2}{*}{ Attribute } & \multicolumn{4}{|c|}{ Group } & \multirow[t]{2}{*}{ SEM } & \multirow[t]{2}{*}{$P$ value } \\
\hline & G1 & G2 & G3 & G4 & & \\
\hline \multicolumn{7}{|c|}{ Nitrogen } \\
\hline Intake & 1.10 & 1.11 & 1.11 & 1.12 & 0.01 & 0.960 \\
\hline \multicolumn{7}{|l|}{ Outgo through } \\
\hline Faeces & 0.28 & 0.29 & 0.30 & 0.30 & 0.00 & 0.386 \\
\hline Urine & 0.14 & 0.14 & 0.15 & 0.15 & 0.00 & 0.386 \\
\hline Total outgo & 0.42 & 0.43 & 0.45 & 0.45 & 0.05 & 0.380 \\
\hline Balance & 0.68 & 0.68 & 0.66 & 0.67 & 0.01 & 0.952 \\
\hline \multicolumn{7}{|c|}{ Calcium } \\
\hline Intake & 0.81 & 0.81 & 0.81 & 0.81 & 0.00 & 0.958 \\
\hline \multicolumn{7}{|l|}{ Outgo through } \\
\hline Faeces* & $0.36^{\mathrm{b}}$ & $0.52^{\mathrm{a}}$ & $0.52^{\mathrm{a}}$ & $0.52^{\mathrm{a}}$ & 0.02 & $<0.001$ \\
\hline Urine & 0.04 & 0.04 & 0.04 & 0.04 & 0.00 & 0.550 \\
\hline Total outgo* & $0.40^{\mathrm{b}}$ & $0.56^{\mathrm{a}}$ & $0.56^{\mathrm{a}}$ & $0.56^{\mathrm{a}}$ & 0.02 & $<0.001$ \\
\hline Balance* & $0.41^{\mathrm{a}}$ & $0.25^{\mathrm{b}}$ & $0.25^{\mathrm{b}}$ & $0.25^{b}$ & 0.02 & 0.009 \\
\hline \multicolumn{7}{|c|}{ Phosphorus } \\
\hline Intake & 0.43 & 0.42 & 0.42 & 0.41 & 0.01 & 0.950 \\
\hline \multicolumn{7}{|l|}{ Outgo through } \\
\hline Faeces & 0.17 & 0.15 & 0.16 & 0.15 & 0.00 & 0.462 \\
\hline Urine & 0.03 & 0.03 & 0.03 & 0.03 & 0.00 & 0.857 \\
\hline Total outgo & 0.20 & 0.18 & 0.19 & 0.18 & 0.00 & 0.330 \\
\hline Balance & 0.23 & 0.24 & 0.23 & 0.23 & 0.00 & 0.422 \\
\hline \multicolumn{7}{|c|}{ Lead (mg/day) } \\
\hline Intake* & $0.06^{\mathrm{b}}$ & $0.65^{\mathrm{a}}$ & $0.64^{\mathrm{a}}$ & $0.65^{\mathrm{a}}$ & 0.06 & $<0.001$ \\
\hline \multicolumn{7}{|l|}{ Outgo through } \\
\hline Faeces* & $0.00^{b}$ & $0.33^{\mathrm{a}}$ & $0.31^{\mathrm{a}}$ & $0.31^{\mathrm{a}}$ & 0.04 & $<0.001$ \\
\hline Urine* & $0.01^{\mathrm{c}}$ & $0.22^{b}$ & $0.24^{b}$ & $0.29^{\mathrm{a}}$ & 0.02 & $<0.001$ \\
\hline Total outgo* & $0.01^{b}$ & $0.55^{\mathrm{a}}$ & $0.55^{\mathrm{a}}$ & $0.60^{c}$ & 0.04 & $<0.001$ \\
\hline Balance* & $0.05^{\mathrm{ac}}$ & $0.10^{\mathrm{b}}$ & $0.08^{b}$ & $0.05^{\mathrm{ac}}$ & 0.01 & 0.026 \\
\hline
\end{tabular}

*Means bearing different superscripts in arrow differ significantly $(\mathrm{p}<0.05)$

Shehata et al., (2011) observed decrease in bodyweight gain in rabbits fed with 0.5 per cent lead acetate in their diets for seven weeks. Flora and Tandon (1986) conducted an experiment on 42 male albino rats and gave them lead acetate as gastric gavage for 56 days and observed a significant decrease in weight gain compared to control group animals. Nabil et al., (2012) also reported significant decrease in the body weight gain in albino rats fed orally with sub lethal doses of lead acetate for 12 weeks, but feed intake in all the groups remained unchanged statistically and feed conversion efficiency was also found to be decreased. Results of the present study indicated that the total lead intake during the whole experimental period was not enough to produce any significant body weight changes in guinea pigs of the experimental groups. 


\section{Digestibility percentage of nutrients}

Statistically no significant differences ( $\mathrm{p}>$ 0.05 ) were obtained between groups with respect to nutrient digestibility. The dry matter digestibility showed no significant difference between groups which was in accordance with Dinius et al., (1973) who supplemented 10 and $100 \mathrm{ppm}$ lead chromate to sixteen bull calves and reported no significant effect of lead on dry matter digestibility. Similar results were obtained by Kumar and Chopra (2003) in dairy calves supplemented with lead acetate in their diets.

Contrary to this, Shehata (2011) observed a decreased dry matter digestibility in rabbits fed with 0.5 per cent lead acetate in their feed. They also reported a decreased organic matter digestibility which was contrary to present result. Dinius et al., (1973) in bull calves and Fick et al., (1976) in wether lambs reported no significant change in organic matter digestibility due to supplementation of lead. Contrary to present results Dildeep et al., (2013) reported a significant $(\mathrm{p}<0.05)$ decrease in ether extract digestibility.

The crude protein digestibility did not show any significant difference between the four groups. This is in accordance with Dinius et al., (1973), but was contrary to the results obtained by Bersenyi et al., (1999) and Shehata et al., (2011) in rabbits in which crude protein digestibility was significantly reduced.

There was no significant decrease in the digestibility of NDF, ADF, hemicellulose and cellulose. Kumar and Chopra (2003) obtained a similar result in cross bred calves supplemented with lead. Contrary results were obtained by Shehata et al., (2011) who reported a reduced fiber digestibility in rabbits fed with 0.5 per cent lead acetate in their diet for a period of seven weeks.
The present results showed no significant difference between the DL-methionine and vitamin $\mathrm{C}$ supplemented groups and it can be concluded that addition of $20 \mathrm{ppm}$ lead alone or along with $20 \mathrm{ppm}$ methionine and 500 ppm vitamin $\mathrm{C}$ had no significant effect on digestibility of nutrients in guinea pigs

Intake and balance (g/d) of nitrogen, calcium, phosphorous and lead in different group of guinea pigs

No significant difference $(\mathrm{P}>0.05)$ was obtained between the groups with regard to nitrogen intake, its outgo through feces and urine and nitrogen balance. Results obtained are in accordance with the results of Fick et al., (1976) who supplemented $1000 \mathrm{mg} \mathrm{Pb} / \mathrm{kg}$ feed to wether lambs. Similar results were obtained by Kumar and Chopra (2003) in cross bred calves with 50 and $100 \mathrm{ppm}$ lead acetate in feed and reported that intake, faecal and urinary nitrogen balance were not affected by lead intake.

The calcium intake showed no significant difference $(p>0.05)$ whereas all lead treated groups showed a higher $(p<0.01)$ fecal excretion of calcium. At the same time all the lead treated groups exhibited a statistically ( $\mathrm{p}$ $<0.01$ ) lower calcium balance. The results are in accordance with Pearl et al., (1983) who reported lower calcium retention in sheep supplemented with lead through feed. The present results indicate the negative interaction between lead and calcium at the intestinal level.

There was no significant difference $(p>0.05)$ between groups in case of phosphorous intake outgo through faeces, urine, and balance. Similar results were obtained by Kumar and Chopra (2003) in cross bred calves.

All the lead supplemented groups showed a higher lead intake obviously due to 
supplementation of lead in feed. Excretion of lead through faeces was significantly $(\mathrm{p}<$ 0.01 ) increased in all the lead supplemented groups. The excretion of lead was also significantly $(p<0.01)$ increased through urine in G2, G3 and G4. Comparatively higher $(\mathrm{p}<0.01)$ excretion of lead through urine was noted in $\mathrm{G} 4$ where vitamin $\mathrm{C}$ was used as ameliorating agent indicating the ameliorative potential.

In conclusion, results of the present study indicated that addition of lower levels of dietary lead does not directly affect the dry matter intake of guinea pigs. Body weight changes in guinea pigs were not affected by dietary lead supplementation. Statistically no significant differences $(\mathrm{p}>0.05)$ were obtained between groups with respect to nutrient digestibility. No significant difference $(\mathrm{P}>0.05)$ was obtained between the groups with regard to nitrogen intake, its outgo through feces and urine and nitrogen balance. The calcium intake showed no significant difference $(\mathrm{p}>0.05)$ whereas all lead treated groups showed a higher ( $\mathrm{p}<$ 0.01 ) fecal excretion of calcium. At the same time all the lead treated groups exhibited a statistically $(\mathrm{p}<0.01)$ lower calcium balance. All the lead supplemented groups showed a higher lead intake. Comparatively higher ( $\mathrm{p}<$ 0.01) excretion of lead through urine was noted in $\mathrm{G} 4$ where vitamin $\mathrm{C}$ was used as ameliorating agent indicating the ameliorative potential.

\section{References}

AOAC. 2000. Official Methods of Analysis. $17^{\text {th }}$ (Ed.) Virginia, USDA, Washington, D.C. USA.

Bersenyi, A., Fekete, S., Hullar, I., Kaclar, I., Szilagyi, M., Glavits, R., Kulesar, M., Mezes, M. and Zoldag, I. 1999. Study on the soil plants (carrot) - animal cycle of nutritive and hazardous minerals in a rabbit model. Acta Veterinaria Hungarica, 47(2), pp 181-190.

Damron, B.L., Simpson, C.F. and Harms, R.H. 1969. The effect of feeding various levels of lead on the performance of broilers. Poult. Sci, 48, pp 1507-1509

Dildeep, V., Dass, R.S. and Garg, A.K. 2013. Effect of dietary lead and methionine on growth, digestibility of nutrients and their utilization in guinea pigs. Indian Vet. J., 90(8), pp 66-69.

Dinius, D.A., Brinsfield, T.H. and Williams, E.E. 1973. Effect of subclinical lead intake on calves. J. Anim. Sci., 37(1), pp 169-173.

Edwards, M.J. and Beatson, J. 1985. Effects of lead and hyperthermia on prenatal brain growth of guinea pigs. Teratology. 30(3), 413-421.

Erdogan, Z., Erdogan, S., Aksu, T. and Baytok, E. 2005. The effect of dietary lead exposure and ascorbic acid on performance, lipid peroxidation status and biochemical parameters of broilers. Turkey J. Vet. Anim. Sci., 29, pp 1053 1059.

Fick, K.R., Ammerman, C.B., Miller, S.M., Simpson, C.F. and Loggins, P.E. 1976. Effect of dietary lead on performance, tissue mineral composition and lead absorption in sheep. j. anim. sci., 42(2), pp 515-523.

Flora, S.J.S. and Tandon, S.K. 1986. Preventive and therapeutic effects of thiamine, ascorbic acid and their combination in lead intoxication. Acta Pharmacol. Toxicol, 58, pp 374-378.

Ibitoye, E.B., Olorede, B.R., Agaie, B.M., Ahmed, A. and Jimoh, A.A. 2011. Effects of dietary lead exposure and graded levels of ascorbic acid supplementation on performance and haematology of broiler chickens. Sokoto J. of Vet. Sci., 9(2), pp $1-6$.

Kumar, A. and Chopra, R.C. 2003. Lead 
concentration in feeds and fodders and its effect on growth, nutrient utilization and certain blood parameters in crossbred calves. Indian J. Anim. Nutr., 20(4), pp 412-420.

Logner, K.R., Neathery, M.W., Miller, W.J., Gentry, R.P., Blackmon, D.M. and White, F.D. 1984. Lead toxicity and metabolism from lead sulfate fed to Holstein calves. J. Dairy Sci., 67, pp 1007-1013.

Pearl, D.S., Ammerman, C.B., Henry, P.R. and Littell, R.C. 1983. Influence of dietary lead and calcium on tissue lead accumulation and depletion, lead metabolism and tissue mineral compostion in sheep. J. Anim. Sci., 56, pp 1416-1426.

Randa, A. H., Dawlat M., Amin, Nariman, A., Rahmy., Hatem, M.E. and Dessouky,
M.I. 2012. Clinicopathological, histopathological and immunolog1ical studies on animals exposed to lead and cadmium under experimental conditions. N Y Sci. J., 5(12), 120-136

Shehata, S.A. 2011.Detoxification of dietary lead by methionine and garlic in rabbits. Nat. Sci. 9(12), pp 1-6.

Talapatra, S.K., Ray, S.N. and Sen, K.C. 1940. Estimation of phosphorus, chlorine, calcium, magnesium, sodium and potassium in foodstuffs. Indian J. Vet. Sci. Anim. Husb., 10, pp 243-246.

Van Soest, P.J., Robertson, J.B. and Lewis, B.A. 1991. Methods of dietary fibre, neutral detergent fibre and non-starch polysaccharides in relation to animal nutrition. J. Dairy Sci. pp 74:35833597.

\section{How to cite this article:}

Bernard, J.K. and Dildeep, V. 2019. DL - Methionine and Vitamin C Effects on Growth and Nutrient Metabolism of Guinea Pigs Supplemented with Dietary Lead. Int.J.Curr.Microbiol.App.Sci. 8(06): 2496-2505. doi: https://doi.org/10.20546/ijcmas.2019.806.299 